\title{
Microbacterium hatanonis sp. nov., isolated as a contaminant of hairspray
}

\author{
Mohammad Abdul Bakir, Takuji Kudo and Yoshimi Benno \\ Microbe Division/Japan Collection of Microorganisms, RIKEN BioResource Center, Wako, \\ Saitama 351-0198, Japan
}

Correspondence

Mohammad Abdul Bakir

bakir@jcm.riken.jp

\begin{abstract}
An aerobic, rod-shaped, Gram-positive, oxidase-negative, catalase-positive bacterial isolate, strain $\mathrm{FCC}-01^{\top}$, originating as a contaminant of hairspray was characterized using phenotypic and molecular taxonomic methods. A $16 \mathrm{~S}$ rRNA gene sequence analysis revealed that the isolate belonged to the genus Microbacterium and represented an evolutionary lineage that was distinct from recognized Microbacterium species. Cell-wall hydrolysate from the isolate contained ornithine and the cell-wall sugars consisted of rhamnose and galactose. The main respiratory quinones were MK-12 (38\%) and MK-11 (35\%). The major cellular fatty acids were anteiso$\mathrm{C}_{15: 0}(48 \%)$, anteiso- $\mathrm{C}_{17: 0}(35 \%)$ and iso- $\mathrm{C}_{16: 0}(11 \%)$. The DNA G+C content was $69 \mathrm{~mol} \%$. The isolate showed $<98 \% 16 \mathrm{~S}$ rRNA gene sequence similarity with respect to all of the Microbacterium species with validly published names. On the basis of the morphological, physiological and chemotaxonomic data and the results of the comparative 16S rRNA gene sequence analysis, this isolate represents a novel species of the genus Microbacterium, for which the name Microbacterium hatanonis sp. nov. is proposed. The type strain is $\mathrm{FCC}-01^{\top}(=\mathrm{JCM}$ $14558^{\top}=$ DSM $19179^{\top}$ ).
\end{abstract}

The genus Microbacterium was described by Orla-Jensen (1919) and the type strain of Microbacterium lacticum (ATCC $8180^{\mathrm{T}}$ ) was isolated during studies on lactic acidproducing bacteria. Collins et al. (1983) and Takeuchi \& Hatano (1998) amended the description of the genus Microbacterium. At the time of writing, the genus Microbacterium comprises 46 species with validly published names, including the recently reported Microbacterium terricola (Kageyama et al., 2007a, b). The Microbacterium species described in the literature have been isolated from milk products, various environmental sources, including soil, water and plants, and from clinical samples, e.g. human blood cultures (Microbacterium resistens and Microbacterium paraoxidans; Funke et al., 1998; Behrendt et al., 2001; Laffineur et al., 2003) and catheter-related bacteraemia samples and bone-marrow products (Funke et al., 1995; Lau et al., 2002; Hirji et al., 2003). Contaminated cosmetic products are relatively uncommon, but certain products can be contaminated with micro-organisms and are unable to suppress the growth of several micro-organisms, representing a potential health hazard. Cosmetic products that were contaminated by bacteria during consumer use have been described by

The GenBank/EMBL/DDBJ accession number for the 16S rRNA gene sequence of strain $\mathrm{FCC}-01^{\top}$ is $\mathrm{AB} 274908$.

Neighbour-joining and minimum-evolution phylogenetic trees and cellular fatty acid compositions for isolate $\mathrm{FCC}-01^{\top}$ in relation to Microbacterium species are available as supplementary material with the online version of this paper.
Brannan \& Dille (1990) and Campana et al. (2006). However, we are unaware of any published information concerned with the occurrence of Microbacterium species in cosmetic products.

A yellow-pigmented bacterium, designated strain FCC- $01^{\mathrm{T}}$, was isolated on trypticase soy agar (TSA) medium at $30{ }^{\circ} \mathrm{C}$ during the course of studies designed to identify microbial contaminants of hairspray. The isolate and reference strains Microbacterium aurum JCM $9179^{\mathrm{T}}$, M. lacticum JCM $1379^{\mathrm{T}}$ and Microbacterium schleiferi JCM $9175^{\mathrm{T}}$ were cultured on TSA for $72 \mathrm{~h}$ at $30{ }^{\circ} \mathrm{C}$. Microbacterium terregens JCM $1342^{\mathrm{T}}$ was cultured on brain-heart infusion agar with soil extract (BHIASE) (JCM medium no. 342; http://www.jcm. riken.jp/cgi-bin/jcm/jcm_grmd?GRMD $=342$ ) at $30{ }^{\circ} \mathrm{C}$ for $72 \mathrm{~h}$. The cell morphology was examined by using light microscopy. For motility testing, the isolate was stabinoculated into tubes containing semi-solid TSA and BHIASE $(0.5 \%)$ and incubated at $30{ }^{\circ} \mathrm{C}$ for up to $72 \mathrm{~h}$ (McClung \& Lindberg, 1957).

Growth at different temperatures $(4,10,20,30,37,41$ and $50{ }^{\circ} \mathrm{C}$ ) was tested on TSA. Anaerobic growth in a $100 \%$ $\mathrm{CO}_{2}$ atmosphere and microaerophily (candle-jar method; Gerhardt et al., 1981) were examined after incubation of the novel strain on the same medium at $30{ }^{\circ} \mathrm{C}$ for 1 week in anaerobic jars. The ability to grow at various $\mathrm{NaCl}$ concentrations $(1,2,5,10$ and $15 \%, \mathrm{w} / \mathrm{v})$ and $\mathrm{pH}$ values (5.0, 6.0, 7.0, 8.0, 9.0 and 10.0; adjusted with $6 \mathrm{M} \mathrm{HCl}$ or $3 \mathrm{M} \mathrm{NaOH}$ ) was examined at $30{ }^{\circ} \mathrm{C}$ using TSA as the basal 
medium. Oxidase activity was tested using tetramethyl- $p$ phenylenediamine and catalase activity was tested using $3 \% \mathrm{H}_{2} \mathrm{O}_{2}$. Commercially available API $20 \mathrm{NE}$ and API ZYM systems were used, according to the instructions of the manufacturer (bioMérieux), to determine the biochemical characteristics.

Cellular fatty acids were analysed by growing cells on TSA and BHIASE for $48 \mathrm{~h}$ at $30{ }^{\circ} \mathrm{C}$. Saponification, methylation and extraction of cellular fatty acids and determination of cellular fatty acid profiles were performed according to the instructions provided with the Sherlock Microbial Identification System (MIDI) as described previously by Sakamoto et al. (2002). Menaquinones were extracted and analysed according to Sakamoto et al. (2002), whole-cell sugars were analysed by using HPLC as described previously (Mikami \& Ishida, 1983) and the amino acid composition was determined according to the method described by Komagata \& Suzuki (1987).

DNA was extracted and purified by following the method described by Marmur (1961). Two universal primers (27F, 5'-AGAGTTTGATCCTGGCTCAG-3'; 1492R, 5' -GGTTACCTTGTTACGACTT-3') were used for PCR amplification of the 16S rRNA gene. The amplified PCR product was purified using a Multiscreen-PCR ${ }_{96}$ filter plate (Millipore) and then sequenced using an ABI Prism BigDye Terminator cycle sequencing ready reaction kit (Applied Biosystems) with an automatic DNA sequencer (model 3100; Applied Biosystems/Hitachi).

An almost-complete 16S rRNA gene sequence (1484 bp) was determined for isolate FCC- $01^{\mathrm{T}}$ and aligned with the $16 \mathrm{~S}$ rRNA gene sequences of representatives of the genus Microbacterium by using CLUSTAL_X software (version 1.81) (Thompson et al., 1997). Parsimony analysis was carried out with the maximum-parsimony method implemented in the PAUP (version 4.0b10) software package (Swofford, 2000). A neighbour-joining (Saitou \& Nei, 1987) phylogenetic tree was inferred using the software package MEGA, version 3.1 (Kumar et al., 2004). Neighbour-joining phylogenetic trees were constructed according to the Kimura-2 model (Kimura, 1980). A minimum-evolution (Rzhetsky \& Nei, 1992) phylogenetic tree was inferred using the same software package. The topologies of the phylogenetic trees were evaluated using bootstrap analysis (Felsenstein, 1985) based on 1000 replications.

The DNA G $+\mathrm{C}$ content was determined using HPLC (Tamaoka \& Komagata, 1984) after enzyme digestion of the DNA to deoxyribonucleosides. An equimolar mixture of four deoxyribonucleotides from a Yamasa GC kit (Yamasa Shoyu) was used as the quantitative standard.

Cells of strain FCC- $01^{\mathrm{T}}$ were aerobic, rod-shaped and Gram-positive. Motility was not observed under the growth conditions used. Colonies were circular, convex with entire margins, moist, shiny and light yellow in colour. The isolate demonstrated microaerophilic growth, but was not able to grow under anaerobic conditions. The isolate grew at $10-37{ }^{\circ} \mathrm{C}$, at a maximum $\mathrm{NaCl}$ concentration of $2 \%$ and at $\mathrm{pH} 6.0-9.0$. Optimum growth was observed at $30{ }^{\circ} \mathrm{C}$ without the addition of $\mathrm{NaCl}$.

The phylogenetic analysis showed that strain $\mathrm{FCC}-01^{\mathrm{T}}$ belongs to the genus Microbacterium (Fig. 1; also see Supplementary Figs S1 and S2 available in IJSEM Online), sharing the highest $16 \mathrm{~S}$ rRNA gene sequence similarity with respect to $M$. schleiferi NBRC $15075^{\mathrm{T}}(97.8 \%)$. The sequence similarities with respect to all of the other Microbacterium species with validly published names were below $98 \%$, the value recognized by the International Committee on Systematics of Prokaryotes Subcommittee on the taxonomy of the suborder Micrococcineae (Schumann \& Evtushenko, 2006) to be sufficient for species delineation at the genotypic level.

The morphological, physiological and chemotaxonomic characteristics of strain FCC- $01^{\mathrm{T}}$ (shown in Table 1 and the species description) were typical of members of the genus Microbacterium (Takeuchi \& Hatano, 1998; Behrendt et al., 2001): the peptidoglycan diamino acid of the strain was ornithine, the major menaquinones were MK-12 (37.5\%), MK-11 (34.8\%) and MK $10(11.6 \%)$ and the predominant fatty acids were anteiso- $\mathrm{C}_{15: 0}$, anteiso- $\mathrm{C}_{17: 0}$ and iso- $\mathrm{C}_{16: 0}$ (Supplementary Table S1). However, strain FCC- $01^{\mathrm{T}}$ clearly differed from phylogenetically related species (Table 1): for instance, in contrast to M. schleiferi, it utilized arabinose as a sole carbon source, produced acid phosphatase, $\alpha$-galactosidase, $\beta$-glucuronidase and $\alpha$-fucosidase and failed to grow at $41{ }^{\circ} \mathrm{C}$. The cell-wall sugars of FCC $-01^{\mathrm{T}}$ were rhamnose and galactose, whereas $M$. schleiferi contained 6-deoxytalose.

The DNA G + C contents of the isolate, M. schleiferi JCM $9175^{\mathrm{T}}$, M. lacticum JCM $1379^{\mathrm{T}}$, M. aurum JCM $9179^{\mathrm{T}}$ and

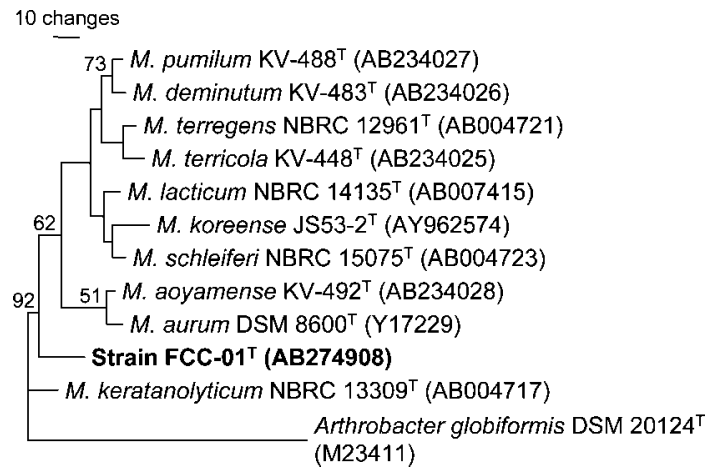

Fig. 1. Maximum-parsimony phylogenetic tree, constructed from a comparative analysis of $16 \mathrm{~S}$ rRNA gene sequences, showing the relationships of isolate $\mathrm{FCC}-01^{\top}$ with respect to type strains of related Microbacterium species. Bootstrap values (expressed as percentages of 1000 replications) $>50 \%$ are shown at branch points. Arthrobacter globiformis DSM $20124^{\top}$ served as the outgroup. Bar, 10 substitutions per site. Neighbour-joining and minimum-evolution phylogenetic trees are given in Supplementary Figs $\mathrm{S} 1$ and $\mathrm{S} 2$. 
Table 1. Characteristics that differentiate isolate $\mathrm{FCC}-01^{\top}$ from phylogenetically related Microbacterium species

Strains/species: 1, strain FCC- $01^{\mathrm{T}}$; 2, M. schleiferi JCM 9175 ${ }^{\mathrm{T}}$; 3, M. terricola; 4, M. keratanolyticum; 5, M. aoyamense; 6, M. terregens JCM 1342 ${ }^{\mathrm{T}}$; 7 , M. aurum JCM $9179^{\mathrm{T}} ; 8$, M. lacticum JCM $1379^{\mathrm{T}}$; 9, M. koreense; 10, M. oleivorans; 11, M. hydrocarbonoxydans; 12, M. resistens. Data for the type strains of M. schleiferi, M. aurum, M. lacticum (API 20NE and API ZYM tests) and M. terregens (API ZYM test) are from this study; other data for these species and data for other reference taxa were taken from Yokota et al. (1993), Funke et al. (1998), Behrendt et al. (2001), Schippers et al. (2005), Kageyama et al. (2006), Lee et al. (2006) and Kageyama et al. (2007a). +, Positive; -, negative; v, variable; w, weak; ND, no data available.

\begin{tabular}{|c|c|c|c|c|c|c|c|c|c|c|c|c|}
\hline Characteristic & 1 & 2 & 3 & 4 & 5 & 6 & 7 & 8 & 9 & 10 & 11 & 12 \\
\hline Colony colour ${ }^{*}$ & LY & Y & $\mathrm{Y}$ & Y & LY & $\mathrm{Y}$ & Y & $\mathrm{Y}$ & LY & $\mathrm{O}$ & Y & $\mathrm{Y}$ \\
\hline $\begin{array}{l}\text { Temperature for growth } \\
\left({ }^{\circ} \mathrm{C}\right)\end{array}$ & $10-37$ & $10-42$ & $10-35$ & 28 & $14-34$ & $20-30$ & $10-42$ & $15-30$ & $20-37$ & $30-37$ & $30-37$ & 37 \\
\hline Growth in $5 \% \mathrm{NaCl}$ & - & - & - & - & + & - & + & - & + & - & - & ND \\
\hline $\begin{array}{l}\text { DNA G + C content } \\
(\mathrm{mol} \%)\end{array}$ & 69.0 & 66.5 & 70.0 & 66.5 & 69.0 & 68.4 & 69.0 & 68.8 & 68.0 & $\mathrm{ND}$ & ND & $\mathrm{ND}$ \\
\hline Major menaquinones & 12,11 & $10,11,12$ & 12,13 & 12,13 & $12,13,14$ & 12,13 & 11,12 & 11,12 & 11,12 & 11,12 & 11,12 & $\mathrm{ND}$ \\
\hline Cell-wall diamino acid $\dagger$ & Orn & Orn & Orn & Orn & Orn & Orn & Lys & Lys & Lys & Lys & Orn & Orn \\
\hline Cell-wall sugar(s) $\ddagger$ & Rha, Gal & $6 \mathrm{dTal}$ & $\mathrm{ND}$ & Gal & Rha, Gal, Xyl & $\begin{array}{c}\text { Rha, Gal, } \\
\text { 6dTal }\end{array}$ & Fuc, Gal, Glc & $\begin{array}{l}\text { Rha, Man, } \\
\text { Gal }\end{array}$ & Gal, Xyl & $\mathrm{ND}$ & $\mathrm{ND}$ & ND \\
\hline Nitrate reduction & - & - & $\mathrm{ND}$ & + & ND & + & - & + & - & $\mathrm{ND}$ & ND & - \\
\hline \multicolumn{13}{|l|}{ Assimilation of: } \\
\hline Glucose & + & w & + & ND & + & - & + & + & + & + & + & ND \\
\hline L-Arabinose & + & - & ND & + & - & - & - & - & - & + & + & - \\
\hline D-Mannose & + & + & + & ND & + & - & $\mathrm{w}$ & + & + & + & + & + \\
\hline D-Mannitol & + & + & ND & ND & + & - & + & + & + & + & + & ND \\
\hline$N$-Acetylglucosamine & - & - & ND & + & + & - & + & + & + & - & + & + \\
\hline Maltose & + & + & + & ND & + & - & + & + & + & + & + & ND \\
\hline Potassium gluconate & + & + & $\mathrm{ND}$ & ND & ND & - & + & + & $\mathrm{ND}$ & + & + & + \\
\hline Malate & $\mathrm{w}$ & - & ND & - & ND & + & - & + & ND & + & + & - \\
\hline Trisodium citrate & - & - & ND & - & $\mathrm{ND}$ & - & - & + & ND & - & + & + \\
\hline Phenylacetic acid & - & - & ND & - & ND & - & - & - & ND & - & + & - \\
\hline \multicolumn{13}{|l|}{ Enzyme activities } \\
\hline Alkaline phosphatase & - & - & + & ND & - & + & - & - & ND & ND & ND & ND \\
\hline Lipase & - & - & $\mathrm{W}$ & ND & + & - & - & - & ND & ND & ND & ND \\
\hline Cystine arylamidase & + & + & + & ND & - & + & + & + & ND & ND & ND & ND \\
\hline Trypsin & + & $\mathrm{w}$ & + & ND & - & + & + & $\mathrm{w}$ & ND & ND & ND & ND \\
\hline Acid phosphatase & + & - & + & ND & + & + & + & + & ND & ND & ND & + \\
\hline$\alpha$-Galactosidase & + & - & $\mathrm{V}$ & ND & - & - & + & - & $\mathrm{ND}$ & ND & ND & - \\
\hline$\beta$-Galactosidase & + & + & ND & ND & + & - & + & + & - & + & + & $\mathrm{ND}$ \\
\hline$\beta$-Glucuronidase & + & - & - & ND & - & - & - & - & ND & - & - & - \\
\hline$\alpha$-Glucosidase & + & + & + & ND & + & + & $\mathrm{W}$ & - & ND & + & + & + \\
\hline$\beta$-Glucosidase & + & + & + & ND & + & w & - & - & ND & + & + & + \\
\hline$\alpha$-Mannosidase & - & - & - & ND & - & - & + & - & ND & + & + & + \\
\hline$\alpha$-Fucosidase & + & - & - & ND & - & - & - & - & ND & ND & ND & + \\
\hline
\end{tabular}

${ }^{*}$ LY, Light yellow; O, orange; Y, yellow.

$\nmid$ Lys, Lysine; Orn, ornithine.

$\ddagger 6 \mathrm{dTal}$, 6-Deoxytalose; Fuc, fucose; Gal, galactose; Glc, glucose; Man, mannose; Rha, rhamnose; Xyl, xylose.

M. terregens JCM $1342^{\mathrm{T}}$ were $69,67,69,69$ and $68 \mathrm{~mol} \%$, respectively. The DNA $\mathrm{G}+\mathrm{C}$ content of the isolate corresponds with those of the members of the genus Microbacterium, which have high G+C contents (66.571.6 mol\%; Takeuchi \& Hatano, 1998).

Taken together, the data presented here indicate that strain FCC- $01^{\mathrm{T}}$ represents a novel species within the genus Microbacterium, for which the name Microbacterium hatanonis sp. nov. is proposed.

\section{Description of Microbacterium hatanonis sp. nov.}

Microbacterium hatanonis (ha.ta.no'nis. N.L. gen. masc. n. hatanonis of Hatano, in honour of Dr Kazunori Hatano, for his contribution to the understanding of the genus Microbacterium).

Aerobic, non-motile, Gram-positive organism. Microaerophilic; does not grow on TSA under an anaerobic atmosphere $\left(\mathrm{CO}_{2}\right)$. Typically, cells are rods, approximately 
$0.8 \mu \mathrm{m}$ wide and $1.7 \mu \mathrm{m}$ long. Colonies are circular, convex with entire margins, moist, shiny and light yellow. The temperature range for growth is $10-37^{\circ} \mathrm{C}$, with optimal growth at $30^{\circ} \mathrm{C}$. The $\mathrm{pH}$ range for growth is 6.0-9.0, with optimal growth at $\mathrm{pH}$ 7.0. No growth occurs at $\mathrm{NaCl}$ concentrations above $2 \%$; optimal growth occurs without the addition of $\mathrm{NaCl}$. Demonstrates positive results for catalase, aesculin hydrolysis, $\beta$-galactosidase and assimilation of glucose, arabinose, mannose, mannitol, maltose and potassium gluconate. Weakly positive for malate assimilation. Gives positive results for the production of esterase, esterase lipase, leucine arylamidase, valine arylamidase, cystine arylamidase, trypsin, acid phosphatase, naphthol-AS-BI-phosphohydrolase, $\alpha$-galactosidase, $\beta$-glucuronidase, $\alpha$-glucosidase, $\beta$-glucosidase and $\alpha$-fucosidase. Shows negative results for oxidase, nitrate reduction, indole production, D-glucose fermentation, arginine dihydrolase, urease, gelatin hydrolysis, utilization of $\mathrm{N}$ acetylglucosamine, capric acid, adipic acid, trisodium citrate and phenylacetic acid and for the production of alkaline phosphatase, lipase, $\alpha$-chymotrypsin and $\alpha$-mannosidase. The DNA G + C content is $69.0 \mathrm{~mol} \%$, the major isoprenoid quinones are MK-12 (37.5\%) and MK-11 $(34.8 \%)$ and the major cellular fatty acids are anteiso- $\mathrm{C}_{15: 0}$ $(48.1 \%)$, anteiso- $\mathrm{C}_{17: 0}(34.7 \%)$ and iso- $\mathrm{C}_{16: 0}(10.5 \%)$. The cell-wall sugars are rhamnose and galactose. Diamino acid ornithine is present in the cell-wall hydrolysates.

The type strain, FCC $-01^{\mathrm{T}}\left(=\mathrm{JCM} 14558^{\mathrm{T}}=\mathrm{DSM} 19179^{\mathrm{T}}\right)$, was isolated from hairspray.

\section{Acknowledgements}

We are grateful to Professor Dr Hans G. Trüper (University of Bonn, Germany) for the etymology of the species epithet. We thank $\mathrm{H}$. Morishita (Research Resources Center, RIKEN Brain Science Institute, Wako, Japan) for analysing the amino acid composition of the cell-wall peptidoglycan.

\section{References}

Behrendt, U., Ulrich, A. \& Schumann, P. (2001). Description of Microbacterium foliorum sp. nov. and Microbacterium phyllosphaerae sp. nov., isolated from the phyllosphere of grasses and the surface litter after mulching the sward, and reclassification of Aureobacterium resistens (Funke et al. 1998) as Microbacterium resistens comb. nov. Int J Syst Evol Microbiol 51, 1267-1276.

Brannan, D. K. \& Dille, J. C. (1990). Type of closure prevents microbial contamination of cosmetics during consumer use. Appl Environ Microbiol 56, 1476-1479.

Campana, R., Scesa, C., Patrone, V., Vittoria, E. \& Baffone, W. (2006). Microbiological study of cosmetic products during their use by consumers: health risk and efficacy of preservative systems. Lett Appl Microbiol 43, 301-306.

Collins, M. D., Jones, D., Keddie, R. M., Kroppenstedt, R. M. \& Schleifer, K. H. (1983). Classification of some coryneform bacteria in a new genus Aureobacterium. Syst Appl Microbiol 4, 236-252.

Felsenstein, J. (1985). Confidence limits on phylogenies: an approach using the bootstrap. Evolution 39, 783-791.
Funke, G., Falsen, E. \& Barreau, C. (1995). Primary identification of Microbacterium spp. encountered in clinical specimens as CDC coryneform group A-4 and A-5 bacteria. J Clin Microbiol 33, 188-192.

Funke, G., Lawson, A., Nolte, F. S., Weiss, N. \& Collins, M. D. (1998). Aureobacterium resistens sp. nov. exhibiting vancomycin resistance and teicoplanin susceptibility. FEMS Microbiol Lett 158, 89-93.

Gerhardt, P., Murray, R. G. E., Costilow, R. N., Nester, E. W., Wood, W. A., Krieg, N. R. \& Phillips, G. R. (1981). Manual of Methods for General Bacteriology. Washington, DC: American Society for Microbiology.

Hirji, Z., Saragosa, R., Dedier, H., Crump, M., Franke, N., Burrows, L., Jamieson, F., Brown, S. \& Gardam, M. A. (2003). Contamination of bone marrow products with an actinomycete resembling Microbacterium species and reinfusion into autologous stem cell and bone marrow transplant recipients. Clin Infect Dis 36, e115-e121.

Kageyama, A., Takahashi, Y. \& Ōmura, S. (2006). Microbacterium deminutum sp. nov., Microbacterium pumilum sp. nov. and Microbacterium aoyamense sp. nov. Int J Syst Evol Microbiol 56, 2113-2117.

Kageyama, A., Takahashi, Y. \& Ōmura, S. (2007a). Microbacterium terricolae sp. nov., isolated from soil in Japan. J Gen Appl Microbiol 53, $1-5$.

Kageyama, A., Takahashi, Y. \& Ōmura, S. (2007b). Microbacterium terricola corrig., sp. nov. In List of New Names and New Combinations Previously Effectively, but not Validly, Published, List no. 116. Int J Syst Evol Microbiol 57, 1371-1373.

Kimura, M. (1980). A simple method for estimating evolutionary rates of base substitutions through comparative studies of nucleotide sequences. J Mol Evol 16, 111-120.

Komagata, K. \& Suzuki, K. (1987). Lipid and cell-wall analysis in bacterial systematics. Methods Microbiol 19, 161-207.

Kumar, S., Tamura, K. \& Nei, M. (2004). MEGA3: integrated software for molecular evolutionary genetics analysis and sequence alignment. Brief Bioinform 5, 150-163.

Laffineur, K., Avesani, V., Cornu, G., Charlier, J., Janssens, M., Wauters, G. \& Delmée, M. (2003). Bacteremia due to a novel Microbacterium species in a patient with leukemia and description of Microbacterium paraoxydans sp. nov. J Clin Microbiol 41, 2242-2246.

Lau, S. K. P., Woo, P. C. Y., Woo, G. K. S. \& Yuen, K.-Y. (2002). Catheter-related Microbacterium bacteremia identified by $16 \mathrm{~S}$ rRNA gene sequencing. J Clin Microbiol 40, 2681-2685.

Lee, J. S., Lee, K. C. \& Park, Y. H. (2006). Microbacterium koreense sp. nov., from sea water in the South Sea of Korea. Int J Syst Evol Microbiol 56, 423-427.

Marmur, J. (1961). A procedure for the isolation of deoxyribonucleic acid from microorganisms. J Mol Biol 3, 208-218.

McClung, L. S. \& Lindberg, R. B. (1957). The study of obligately anaerobic bacteria. In Manual of Microbiological Methods, pp. 120139. Edited by H. J. Conn. New York: McGraw-Hill.

Mikami, H. \& Ishida, Y. (1983). Post-column fluorometric detection of reducing sugars in high-performance liquid chromatography using arginine. Bunseki Kagaku 32, E207-E210.

Orla-Jensen, S. (1919). The Lactic Acid Bacteria. Copenhagen: Høst and Son.

Rzhetsky, A. \& Nei, M. (1992). A simple method for estimating and testing minimum-evolution trees. Mol Biol Evol 9, 945-967.

Saitou, N. \& Nei, M. (1987). The neighbor-joining method: a new method for reconstructing phylogenetic trees. Mol Biol Evol 4, 406-425.

Sakamoto, M., Suzuki, M., Umeda, M., Ishikawa, I. \& Benno, Y. (2002). Reclassification of Bacteroides forsythus (Tanner et al. 1986) as 
Tannerella forsythensis corrig., gen. nov., comb. nov. Int J Syst Evol Microbiol 52, 841-849.

Schippers, A., Bosecker, K., Spröer, C. \& Schumann, P. (2005). Microbacterium oleivorans sp. nov. and Microbacterium hydrocarbonoxydans sp. nov., novel crude-oil-degrading Gram-positive bacteria. Int J Syst Evol Microbiol 55, 655-660.

Schumann, P. \& Evtushenko, L. I. (2006). International Committee on Systematics of Prokaryotes Subcommittee on the taxonomy of the suborder Micrococcineae. Minutes of the meeting, 24 July 2005, San Francisco, CA, USA. Int J Syst Evol Microbiol 56, 2721-2722.

Swofford, D. L. (2000). PAUP ${ }^{*}$ : phylogenetic analysis using parsimony (and other methods), version 4. Sunderland, MA: Sinauer Associates.

Takeuchi, M. \& Hatano, K. (1998). Union of the genera Microbacterium Orla-Jensen and Aureobacterium Collins et al. in a redefined genus Microbacterium. Int $J$ Syst Bacteriol 48, 739-747.

Tamaoka, J. \& Komagata, K. (1984). Determination of DNA base composition by reversed-phase high-performance liquid chromatography. FEMS Microbiol Lett 25, 125-128.

Thompson, J. D., Gibson, T. J., Plewniak, F., Jeanmougin, F. \& Higgins, D. G. (1997). The CLUSTAL_X windows interface: flexible strategies for multiple sequence alignment aided by quality analysis tools. Nucleic Acids Res 25, 4876-4882.

Yokota, A., Takeuchi, M., Sakane, T. \& Weiss, N. (1993). Proposal of six new species in the genus Aureobacterium and transfer of Flavobacterium esteraromaticum Omelianski to the genus Aureobacterium as Aureobacterium esteraromaticum comb. nov. Int J Syst Bacteriol 43, 555-564. 